\title{
Tertib hukum pembentukan peraturan perundang-undangan pasca putusan Mahkamah Konstitusi
}

\section{Haru Permadi}

Haru Permadi; Fakultas Hukum Universitas Brawijaya; Jalan MT. Haryono 169 Malang; 65145; Jawa Timur; Indonesia.

\section{ARTICLEINFO}

Article history:

Received 2019-12-24

Received in revised form

2020-03-24

Accepted 2020-04-01

Kata kunci:

Kepastian Hukum; Tertib Hukum.

Keywords:

Legal Certainty; Law Orderly.

DOI: $h$ ttps://doi.org/10.26905/

idjch.v11i1.3642.

How to cite item:

Permadi, H. (2020). Tertib Hukum pembentukan peraturan perundang-undangan pasca putusan Mahkamah Konstitusi. Jurnal Cakrawala Hukum, 11(1),5059. doi:10.26905/idjch.v11i1.3642.

\begin{abstract}
Abstrak
Negara hukum aspek utama yang harus diperhatikan adalah adanya kepastian hukum. Kepastian hukum dapat terwujud dengan pemerintah membentuk peraturan perundang-undangan yang tidak bertentangan antar komponen hukum. Salah satu komponen hukum adalah putusan pengadilan yang dalam artikel ini focus pada putusan Mahkamah Konstitusi. Putusan Mahmakah Konstitusi salah satunya adalah putusan atas pengujian Undang-Undang terhadap Undang-Undang Dasar. Dalam putusan tersebut terdapat pernyatan bertentangan atau tidak bertentangan suatu norma yang diuji dengan Undang-Undang Dasar. Penulisan artikel ini bertujuan untuk meneliti apakah putusan Mahkamah Konstitusi diperhatikan oleh pembentuk peraturan perundang-undangan demi mewujudkan kepastian hukum. Penulisan artikel ini menggunakan metode penelitian doctrinal atau biasa disebut dengan penelitian normative. Hasil penelitian menunjukkan bahwa terdapat peraturan perundang-undangan yang dibentuk bertentangan dengan putusan Mahkamah Konstitusi khususnya terkait dengan pendapat hukum hakim terhadap konstitusionalitas suatu norma tertentu. Peraturan Menteri Hukum dan Hak Asasi Manusia Nomor 14 Tahun 2019 tentang Pengesahan Koperasi menyebutkan dalam Pasal 6 ayat (3) jenis koperasi ada lima, padahal putusan Mahkamah Konstitusi menyebutkan bahwa pembatasan jenis koperasi akan memasung kreatifitas koperasi. Oleh karenanya jaminan akan kepastian hukum dalam peraturan perundangundangan tidak terwujud.
\end{abstract}

\section{Abstract}

The state of law the main aspect that must be considered is legal certainty. Legal certainty can be realized with the government forming legislation that does not conflict between legal components. One component of the law is a judicial decisions which in this article focuses on the Constitutional Court's decisions. One of the

Corresponding Author:

* Haru Permadi.

E-mail address: harupermadi12@gmail.com 


\section{Jurnal Cakrawala Hukum, Volume 11 No. 1 April 2020 \\ ISSN PRINT 2356-4962 ISSN ONLINE 2598-6538}

Constitutional Court's decisions is the decision on the examination of the Act against the Constitution. In that decision there are statements that contradict or not contradict a norm that is tested by the Constitution. This research purpose is to examine whether the Constitutional Court's decisions is considered by the legislators to realize legal certainty. A method of writing in this research uses the method of doctrinal research or commonly referred to as normative research. The research results show that there are legislations which are formed in opposition of the Constitutional Court's decisions particularly relating to judge the legal opinion. Minister of Law and Human Rights Regulation No. 14 of 2019 concerning Ratification of Cooperatives mentions in Article 6 paragraph (3) there are five types of cooperatives, whereas the Constitutional Court's decisions mentions that restrictions on the type of cooperatives will block the creativity of cooperatives. Therefore the guarantee of legal certainty in the legislation does not materialize.

\section{Latar Belakang}

Pasal 1 ayat (3) Undang-Undang Dasar Negara Republik Indonesia Tahun 1945 (UUD NRI 1945) menyebutkan bahwa: "Indonesia adalah negara hukum". Mengacu pada Pasal 1 ayat (3) tersebut maka segala segala hal yang dilakukan di Indonesia harus ada dasar hukumnya terlebih dahulu sebelum suatu tindakan dilakukan. Digunakannya hukum sebagai acuan dasar suatu tindakan menunjukkan bahwa supremasi hukum adalah dasar hal penting dan seharusnya terwujudnya sistem pemerintah yang menjunjung tinggi hak asasi manusia dan terjaminnya persamaan dihadapan hukum dan pemerintahan bagi warga negara adalah tolok ukur supremasi hukum (Jefrry, 2015).

Pemberlakuan konsep negara hukum yang menjunjung tinggi supremasi hukum tentu berorientasi pada terwujudnya tujuan hukum. Secara teoritis, Gustav Radbruch sebagaimana dikutip Ahmadi Ali menyebutkan bahwa tujuan hukum adalah keadilan, kemanfaatan, dan kepastian hukum (Ali, 2017). Terkait dengan pandangan dari Gustav Radburch terkait dengan tujuan hukum tersebut, salah satu aspek menarik adalah mengenai kepastian hukum. Kepastian hukum tentu bermakna jelasnya suatu hal tertentu. Sebagai contoh apabila dikaitkan dengan peraturan perundang-undangan maka kepastian hukum berarti peraturan perundang-undangan harus jelas, tidak ada pertentangan antar peraturan perundangundangan, dan tidak adanya kekaburan peraturan perundang-undangan. Dalam konteks kepastian hukum dalam peraturan perundang-undangan, Indonesia membentuk Undang-Undang Nomor 12 Tahun 2011 tentang Pembentukan Peraturan Perundang-undangan (UU 12/2011). UU 12/2011 sebagai pedoman dalam membentuk peraturan perundang-undangan dalam Pasal 5 huruf $\mathrm{f}$ menyebutkan bahwa dalam membentuk peraturan perundang-undangan harus dilakukan berdasarkan pada asas kejelasan rumusan. Penjelasan Pasal 5 huruf $f$ menyebutkan bahwa:

"Yang dimaksud dengan "asas kejelasan rumusan" adalah bahwa setiap Peraturan Perundang-undangan harus memenuhi persyaratan teknis penyusunan Peraturan Perundang-undangan, sistematika, pilihan kata atau istilah, serta bahasa hukum yang jelas dan mudah dimengerti sehingga tidak menimbulkan berbagai macam interpretasidalam pelaksanaannya"

Lebih lanjut, Pasal 6 huruf i UU 12/2011 menyebutkan bahwa materi muatan peraturan perundang-undangan harus mencerminkan asas ketertiban dan kepastian hukum. Penjelasan atas Pasal 6 huruf i menyebutkan bahwa:

"Yang dimaksud dengan "asas ketertiban dan kepastian hukum" adalah bahwa setiap Materi Muat- 
an Peraturan Perundang-undangan harus dapat mewujudkan ketertiban dalam masyarakat melalui jaminan kepastian hukum."

Berdasarkan kedua asas terkait pembentukan peraturan perundang-undangan tersebut, aspek yang ditekankan adalah setiap peraturan perundang-undangan harus jelas sehingga tidak menimbulkan interplasi (kekaburan) dan harus mewujudkan ketertiban melalui jaminan kepastian hukum. Untuk mewujudkan hal tersebut tentunya pembentuk peraturan perundang-undangan harus cermat dalam proses penyusunan norma dalam setiap peraturan perundang-undangan. Bentuk kecermatan tersebut penting untuk menghindari pertentangan antar peraturan perundang-undangan dan antara peraturan perundang-undangan dengan komponen hukum lainnya.

Salah satu komponen hukum di Indonesia adalah putusan hakim. Putusan hakim merupakan komponen hukum karena putusan hakim dapat menciptakan hukum apalagi apabila putusan tersebut diikuti oleh hakim-hakim selanjutnya dalam memutus perkara yang sama. Khusus terkait dengan peraturan perundang-undangan, putusan hakim yang sangat terkait adalah putusan hakim Mahkamah Konstitusi (MK). sebagaimana diketahui, dalam Pasal 24C UUD NRI 1945, disebutkan bahwa salah satu kewenangan MK adalah memutus pengujian Undang-Undang terhadap UUD NRI 1945.

Dalam putusan MK terkait dengan pengujian Undang-Undang terhadap UUD NRI 1945, MK dapat memutus suatu norma dalam UndangUndang atau bahkan Undang-Undang bertentangan dengan UUD NRI 1945 sehingga dinyatakan tidak mempunyai kekuatan hukum mengikat. Sebelum menjatuhkan putusan putusan bahwa suatu norma bertentangan atau tidak dengan UUD NRI 1945, hakim MK melakukan pertimbangan hukum. Dalam pertimbangan hukum hakim MK ini berisi tafsir dan pendapat hakim MK atas suatu norma dalam Undang-Undang. Oleh karena putusan hakim MK merupakan bagian dari komponen hukum, maka dalam pembentukan peraturan perundang-undangan, putusan hakim MK harus diperhatikan. Apabila tidak diperhatikan maka yang terjadi adalah norma yang dinyatakan bertentangan dengan UUD NRI 1945 dapat 'hidup' lagi. Dalam keadan demikian, tentua kepastian hukum tidak terwujud. Atas dasar latar belakang tersebut, artikel ini disusun.

\section{Metode}

Metode Penelitian dalam penulisan artikel ini adalah metode penelitian doctrinal atau biasa disebut dengan penelitian hukum normative. Metode penelitian normative mengutip pendapat Terry Hutchinson yang dikutip oleh Peter Mahmud adalah penelitian sistematis untuk menjelaskan secara sistematis aturan suatu kategori hukum tertentu serta mengalisis hubungan antara peraturan atas kesulitan serta memprediksi pembangunan hukum ke depan (Marzuki, 2011). Dalam metode penelitian normative ini digunakan metode pendekatan peraturan perundang-undangan (statute approach) dan pendekatan teoritis (theoretical approach). Pendekatan peraturan perundangundangan digunakan untuk mengetahui peraturan perundang-undangan yang materi muatannya tidak sesuai dengan putusan MK. Pendekatan teoritis digunakan sebagai acuan dalam merumuskan kepastian hukum dalam pembentukan peraturan perundang-undangan.

\section{Pembahasan}

\subsection{Sifat putusan MK dan kewenangan MK}

Putusan hakim MK dari aspek sifatnya berbeda dengan putusan hakim di peradilan lainnya. Putusan hakim MK dalam Pasal 24C UUD NRI 1945 disebutkan bersifat final. (Safaat dkk, 2015). Mengenai putusan yang bersifat final tersebut, Muchamad Ali Safaat dan kawan-kawan menye- 
butkan bahwa terhadap putusan MK tidak dapat dilakukan upaya hukum. Secara normatif pengertian putusan yang sifatnya final disebutkan dalam UU 8/2010 angka 8 terkait dengan Penjelasan Pasal 10 yang menyebutkan bahwa:

"Putusan Mahkamah Konstitusi bersifat final, yakni putusan Mahkamah Konstitusi langsung memperoleh kekuatan hukum tetap sejak diucapkan dan tidak ada upaya hukum yang dapat ditempuh. Sifat final dalam putusan Mahkamah Konstitusi dalam Undang-Undang ini mencakup pula kekuatan hukum mengikat (final and binding)"

Putusan hakim MK bersifat final dan mengikat, maka tidak ada upaya hukum apapun yang dapat ditempuh apabila terdapat pihak keberatan dengan putusan hakim MK. Mahkamah Konstitusi sebagai lembaga peradilan baru yang dibentuk pasca amandemen UUD 1945 secara kelembagaan kewenangannya diberikan oleh UUD NRI 1945 dalam Pasal 24C ayat (1). Pasal 24C ayat (1) UUD NRI 1945 menyebutkan bahwa MK berwenang untuk: 1. Menguji undang-undang terhadap Undang-Undang Dasar; 2. Memutus sengketa kewenangan lembaga negara yang kewenangannya diberikan Undang-Undang Dasar; 3. Memutus pembubaran partai politik; dan 3. Memutus perselisihan hasil pemilihan umum.

Selain kewenangan tersebut, MK memiliki 1 (satu) kewajiban yang disebutkan dalam Pasal 24C ayat (2) yaitu memberikan putusan atas pendapat Dewan Perwakilan Rakyat mengenai dugaan pelanggaran oleh Presidan dan/atau Wakil Presiden menurut Undang-Undang Dasar.

Pembentukan MK sebagai lembaga peradilan baru di Indonesia menjadi kesempatan bagi pencari keadilan konstitusi. Terkait hal tersebut, konsideran menimbang huruf a UU 24/2003 menyebutkan bahwa:

"Mahkamah Konstitusi sebagai salah satu pelaku kekuasaan kehakiman mempunyai peranan penting dalam usaha menegakkan konstitusi dan prinsip negara hukum sesuai dengan tugas dan wewenangnya sebagaimana ditentukan dalam UndangUndang Dasar Negara Republik Indonesia Tahun 1945"

Selama Indonesia merdeka sampai dengan tahun 2002, apabila terdapat warga negara Indonesia yang merasa dirugikan akibat berlakunya Undang-Undang tidak dapat melakukan upaya hukum apapun. Saat ini apabila terdapat UndangUndang yang dianggap merugikan warga negara Indonesia karena bertentangan dengan UUD NRI 1945, Undang-Undang tersebut dapat dimintakan pembatalan ke MK. Pembatalan terhadap suatu Undang-Undang dilakukan oleh MK apabila Undang-Undang tersebut dianggap bertentangan dengan UUD NRI 1945. Atas hal tersebut tepat apabila Penjelasan Undang-Undang Nomor 24 Tahun 2003 tentang Mahkamah Konstitusi menyebutkan bahwa

"Keberadaan Mahkamah Konstitusi sekaligus untuk menjaga terselenggaranya pemerintahan negara yang stabil, dan juga merupakan koreksi terhadap pengalaman kehidupan ketatanegaraan di masa lalu yang ditimbulkan oleh tafsir ganda terhadap konstitusi"

Negara hukum, tafsir konstitusi yang dilakukan oleh lembaga peradilan sangat penting untuk menghindari penyalahgunaan konstitusi. Konstitusi (UUD NRI 1945) merupakan cerminan kehidupan politik masyarakat sebagai suatu kenyataan (die politische verfassung als gesellschaftliche wirklichkeit) (Syahuri, 2011). Mengacu pada hal tersebut, maka dapat ditarik kesimpulan bahwa menegakkan konstitusi adalah menegakkan/menghormati kehidupan politik di masyarakat.

Pasca dibentuknya MK dalam amandemen UUD NRI 1945 yang kemudian dikukuhkan melalui Undang-Undang Nomor 24 Tahun 2003 tentang Mahkamah Konstitusi (UU 24/2003), pengujian Undang-Undang terhadap UUD NRI 1945 mencapai angka 1.973. Dari 1.973 perkara yang diajukan 
ke MK tersebut, permohonan yang dikabulkan sejumlah 262, ditolak, 460, tidak dapat diterima 401, ditarik kembali 121, gugur 22, dan tidak berwenang 9 (www.mahkamahkonstitusi.go.id). Angka pengujian Undang-Undang terhadap UUD NRI 1945 tersebut setidaknya menunjukkan bahwa kesatu masih banyak Undang-Undang yang dinilai tidak sesuai dengan UUD NRI 1945, kedua pembentuk Undang-Undang abai terhadap UUD NRI 1945 dalam membentuk Undang-Undang, dan ketiga kesadaran masyarakat terhadap supremasi UUD NRI 1945 meningkat.

\subsection{Putusan MK dalam pembentukan peraturan perundang-undangan}

Putusan hakim MK sebagaimana putusan hakim lainnya merupakan putusan untuk mengakhiri suatu perkara yang terjadi. Mengenai putusan hakim MK, putusan yang dikeluarkan terkait dengan pengujian Undang-Undang adalah putusan yang menyatakan bahwa suatu norma dalam Undang-Undang atau bahkan seluruh UndangUndang bertentangan atau tidak bertentangan dengan UUD NRI 1945.

Apabila suatu norma atau seluruh UndangUndang dinilai bertentangan dengan UUD NRI 1945, hakim MK akan memutus bahwa norma atau seluruh Undang-Undang tidak mempunyai kekuatan yang mengikat. Pernyataan bertentangan dan tidak mempunyai kekuatan hukum yang mengikat dalam putusan MK terletak dalam amar putusan. Dari anatomi putusan MK, sebelum amar putusan terdapat pertimbangan hukum hakim yang digunakan sebagai pertimbangan untuk menentukan suatu permohonan dikabulkan atau tidak. Sebagai contoh adalah pertimbangan hukum hakim dalam Putusan Nomor 28/PUU-XI/2013.

Pertimbangan hukum putusan tersebut terdapat pendapat hakim atas paal-pasal yang diuji. Pendapat hakim atas pengujian Pasal 1 angka 1 Undang-Undang Nomor 17 Tahun 2012 tentang
Perkoperasian (UU 12/2012) menyebutkan dibagian akhir bahwa Permohonan pemohon beralasan menurut hukum (Putusan Nomor 28/PUU-XI/ 2013). Karena Permohonan beralasan menurut hukum, maka permohonan pemohon dikabulkan. Mengacu pada contoh tersebut, maka pendapat hakim atas suatu permohonan mempengaruhi amar putusan hakim. Terkait dengan pendapat hakim atas suatu norma yang diuji, pendapat tersebut merupakan tafsir resmi atas suatu norma yang diuji.

Dengan kata lain apabila hakim telah memutus bahwa suatu norma bertentangan dengan UUD NRI 1945, idealnya norma tersebut tidak boleh 'dihidupkan' kembali karena bertentangan dengan UUD NRI 1945. Tidak dihidupkan kembali norma yang telah dinyatakan bertentangan dengan UUD NRI 1945 dalam Undang-Undang atau peraturan perundang-undangan lainnya berdampak pada kepastian hukum atas suatu norma. Namun apabila norma yang telah dinyatakan bertentangan dengan UUD NRI 1945 'dihidupkan' kembali, maka terjadi pengulangan kesahalan pembentukan norma yang dilakukan pembentuk peraturan perundang-undangan yang tentunya berdampak pada kepastian hukum atas suatu norma.

Terkait dengan ketaatan pembentuk peraturan perundang-undangan atas putusan MK, beberapa peraturan perundang-undangan nampak tidak sesuai dengan putusan MK. Putusan MK Nomor 28/PUU-XI/2013 menentukan beberapa hal terkait dengan norma yang diuji dalam UU 17/ 2012. Berikut adalah beberapa norma yang diuji dan pendapat MK atas norma yang diuji tersebut:

1. Pengertian Koperasi

"Menurut Mahkamah, koperasi pada hakikatnya merupakan bagian dari tata susunan ekonomi Indonesia yang diamanatkan oleh Pasal 33 ayat (1) UUD 1945. ... Koperasi sebagai bagian dari suatu tata susunan ekonomi mesti didesain, disosialisasikan, diperjuangkan, dan dilaksanakan, bukan tata susunan yang diserahkan kepada mekanisme pasar, 


\section{Jurnal Cakrawala Hukum, Volume 11 No. 1 April 2020}

ISSN PRINT 2356-4962 ISSN ONLINE 2598-6538

meski pasar harus menjadi perhatian penting dalam percaturan perekonomian nasional. Dengan demikian maka sistem perekonomian nasional merupakan sistem perekonomian yang berkarakter. Nilai yang dijunjung tinggi yang kemudian menjadi karakter tersebut telah dirumuskan dalam Pasal 33 ayat (1) UUD 1945 yaitu suatu tata susunan ekonmi sebagai usaha bersama berdasar atas asas kekeluargaan.

Artinya, nilai sosial yang dijunjung tinggi dan diimplementasikan oleh bangsa yang kemudian menjadi karakter tersebut di dalam UU 1945 dirumuskan menjadi demokrasi ekonomi yang bertumpu pada dasar usaha bersama dan asas kekeluargaan."

(halaman 240 Putusan MK 28/PUU-XI/2013)

2. Kewenangan Pengawas

"Kewenangan pengawas harus dikaitkan dengan hakikat koperasi sebagai salah satu entitas penting dalam sistem ekonomi yang berkarakter demokrasi. ... Kewenangan pengawas untuk mengusulkan pengurus, menerima dan menolak anggota baru, memberhentikan anggota, serta memberhentikan pengurus untuk sementara waktu bertentangan dengan prinsip demokrasi ekonomi sebagaimana dimaksud dalam Pasal 33 ayat (1) UUD 1945, dan menyebabkan kedaulatan anggota dan eksistensi RAT direduksi dan dinegasi."

(halaman 244 Putusan MK 28/PUU-XI/2013)

3. Pengangkatan Pengurus dari Non Anggota "Pengangkatan pengurus dari non-anggota menghalangi atau bahkan menegasikan hak anggota koperasi untuk menyatakan pendapat, memilih dan dipilih, serta nilai kekeluargaan, bertanggungjawab, demokrasi, dan persamaan yang menjadi dasar koperasi, serta nilai keterbukaan dan tanggung jawab yang diyakini anggota koperasi yang kesemuanya merupakan derivasi dari demokrasi ekonomi dalam Pasal 33 ayat (1) UUD 1945."

(halaman 245 Putusan MK 28/PUU-XI/2013)

4. Modal Koperasi

"Keharusan untuk membeli sertifikat modal koperasi adalah norma yang tidak sesuai dengan prinsip koperasi yang bersifat sukarela dan terbuka yang merupakan derivasi dari Pasal 33 ayat (1) UUD 1945 yaitu sebagai usaha bersama berdasar atas asas kekeluargaan, karena ketentuan tersebut (keharusan membeli modal koperasi) jelas bahwa modal materiil telah menjadi hal utama dalam berkoperasi... Modal materiil dan finansial merupakan hal yang penting, namun konsep modal koperasi harus berlindan dengan makna' 'perekonomian disusun sebagai usaha bersama berdasar atas asas kekeluargaan. ... Modal sosial memiliki makna dan tujuan utama mencapai kesejahteraan sosial. Didalamnya terkandung nilai:

1) Saling percaya antar individu maupun antar kelompok (trust);

2) Pranata sosial (institution); dan

3) Jaringan sosial (network)." (halaman 247-248 Putusan MK 28/PUU-XI/ 2013)

5. Pembatasan Pemberian Susplus Hasil Usaha yang berasal dari transaksi dengan non anggota "Anggota koperasi sebagai pemilik dan pengguna jasa seharusnya menerima surplus hasil usaha, baik dari transaksi yang berasal dari anggota maupun dari non-anggota. ... Pembatasan membagikan surplus hasil usaha justru mencerminkan ketidakberpihakan pada anggota koperasi sebagai pemilik koperasi. Dalam hal ini seharusnya yang dikedepankan justru mencari laba untuk memberi kesejahteraan kepada anggotanya, sehingga setidak-tidaknya, dibagi atau tidak dibaginya surplus hasil usaha, ketentuannya diserahkan kepada anggota dengan menggunakan mekanisme yang tersedia." (halaman 250 Putusan MK 28/PUU-XI/2013)

6. Jenis Koperasi

"Membatasi jenis kegiatan usaha koperasi hanya empat jenis telah memasung kreatifitas koperasi untuk menentukan sendiri jenis kegiatan usaha, yang bisa jadi berseiring dengan perkembangan ilmu pengetahuan, teknologi, budaya, dan ekonomi, berkembang pula jenis kegiatan usaha untuk memenuhi kebutuhan ekonomis manusia. Terlebih lagi manakala ketentuan tersebut dimaknai bahwa satu koperasi harus memilih satu jenis kegiatan usaha. ... Membatasi jenis usaha koperasi dengan menentukan satu jenis usaha koperasi (single purpose co- 
operative) bertentangan dengan hakikat koperasi sebagai organisasi kolektif dengan tujuan memenuhi keperluan hidup untuk mencapai kesejahteraan anggota... Seharusnya satu koperasi sebagai usaha bersama diberi keleluasaan berusaha tanpa membatasi satu koperasi dengan satu jenis usaha tertentu, melainkan sangat tergantung pada kehendak para anggota sesuai kebutuhan yang dihadapinya." (halaman 251-252 Putusan MK 28/PUU-XI/ 2013)

Beberapa pendapat hakim MK atas norma yang diuji dalam Putusan MK 28/PUU-XI/2013 tersebut merupakan tafsir hakim MK atas konstitusionalitas norma yang diuji. Penafsiran atas beberapa norma dan penafsiran tersebut dapat diartikan bahwa apabila hendak melakukan pengaturan/penormaan terhadap suatu hal yang pernah diuji supaya konstitusional harus dilakukan sesuai dengan pendapat hakim MK. Sebagai contoh adalah apabila pemerintah hendak membuat peraturan perundang-undangan mengenai koperasi yang didalamnya mengatur mengenai jenis anggota maka pendapat hakim MK atas jenis Koperasi harus dijadikan acuan. Jenis koperasi berdasar pendapat hakim MK dalam putusan nomor 28/PUU-XI/2013 tidak boleh dibatasi karena akan memasung kreatifitas koperasi. Dengan kata lain, pengaturan jenis usaha koperasi tidak boleh dibatasi. Sebagai contoh lain adalah mengenai modal koperasi. Modal koperasi berdasar pendapat hakim MK harus bersifat sukarela dan terbuka. Atas hal tersebut maka pengaturan modal koperasi tidak boleh atas dasar paksaan.

Permasalahan kemudian terjadi ketika pemerintah membentuk Peraturan Menteri Hukum dan Hak Asasi Manusia Nomor 14 Tahun 2019 tentang Pengesahan Koperasi (Perkumham 14/2019). Dalam Pasal 6 ayat (3) Perkumham 14/2019 disebutkan bahwa jenis koperasi terdiri atas: a. Produsen; b. Konsumen; c. Pemasaran; d. Jasa; dan e. Simpan pinjam.
Penyebutan jenis koperasi yang dibatasi hanya 5 (lima) jenis tersebut tentu berbeda dan bertentangan dengan pendapat MK yang menyatakan bahwa membatasi jenus usaha koperasi akan memasung kreatifitas koperasi untuk menentukan sendiri jenis kegiatan usaha, padahal dalam kondisi era teknologi saat ini koperasi dapat meyelenggarakan usaha berbasis teknologi untuk memenuhi kebutuhan ekonomis manusia.

Permenkumham 14/2019 merupakan peraturan yang digunakan untuk mengatur pengesahan koperasi. Pengesahan koperasi dilakukan apabila koperasi telah memenuhi persyaratan-persyaratan yang ditentukan. Pasal 3 Permenkumham 14/2019 menyebutkan bahwa pengesahan Akta Pendirian koperasi diajukan kepada Menteri melalui Direktur Jenderal oleh para pendiri atau luasa para pendiri melalui Sistem Administrasi Badan Hukum. Pengajuan permohonan pengesahan tersebut harus didahului dengan pengajuan nama koperasi sebagaimana diatur dalam Pasal 4 ayat (1). Nama koperasi tersebut sesuai dengan Pasal 7 ayat (1) harus memenuhi persyaratan yaitu kesatu terdiri dari paling sedikit 3 (tiga) kata setelah frasa koperasi dan jenis koperasi, belum dipakau secara sah oleh koperasi lain, tidak bertentangan dengan ketertiban umum dan/atau kesusilaan, dan beberapa persyaratan lainnya.

Sesunggunya terkait dengan persyaratanpersyaratan teknis sebagaimana telah disebutkan diatas, tidak terdapat permasalahan mengingat Permenkumham 14/2019 dapat disebut sebagai peraturan teknis yang oleh karenya pengaturannya sangat konkrit dan detail. Namun permasalahannya adalah ketika penjabaran atau pengaturan mengenai pengesahan Koperasi ini melalukan pembatasan mengenai jenis usaha koperasi yang dalam putusan MK pembatasan tersebut dinilai memasung kreatifitas koperasi sehingga dianggap bertentangan dengan UUD NRI 1945. Pembatasan jenis usaha koperasi tersebut tentu melanggar putusan hakim MK, dan oleh karenanya jelas 


\section{Jurnal Cakrawala Hukum, Volume 11 No. 1 April 2020}

ISSN PRINT 2356-4962 ISSN ONLINE 2598-6538

terdapat materi muatan dalam Permenkumham 14/ 2019 yang tidak bertentangan dengan komponen hukum lainnya dalam sistem hukum Indonesia.

Pengaturan yang tidak sesuai atau bertentangan dengan putusan MK 28/PUU-XI/2019 tersebut jelas menimbulkan ketidakpastian hukum dalam berkoperasi. Pembentukan norma yang menghidupkan kembali norma yang dinilai bertentangan dengan UUD NRI 1945 sama artinya dengan memberikan ketidakpastian atas kebolehan pengaturan suatu hal di Indonesia. Masyarakat yang menyelenggarakan koperasi disatu sisi berdasar putusan MK nomor 28/PUU-XI/2019 meyakini bahwa usaha koperasi dapat dilakukan sesuai dengan kreatifitas mereka tanpa adanya pemasungan, namun disisi lain berdasarkan Permenkumham 14/2019 jenis usaha mereka dibatasi sehingga kreatifitas koperasi terpasung.

Apabila mengacu pada UU 12/2011, sesungguhnya materi muatan peraturan perundangundangan termasuk Permenkumham 14/2019 harus dapat mewujudkan ketertiban dalam masyarakat melalui jaminan kepastian hukum. Hal tersebut dapat terwujud apabila seluruh faktor termasuk putusan MK diperhatikan dalam proses pembentukan peraturan perundang-undangan. Pemerintah selaku pembentuk peraturan perundang-undangan idealnya pasti mengetahui putusan MK. Apalagi dalam Pasal 59 ayat (1) UndangUndang Nomor 8 Tahun 2011 tentang Perubahan Atas Undang-Undang Nomor 24 Tahun 2003 tentang Mahkamah Konstitusi (UU 8/2011) menyebutkan bahwa:

"Putusan Mahkamah Konstitusi mengenai pengujian undang-undang terhadap Undang-Undang Dasar Negara Republik Indonesia Tahun 1945 disampaikan kepada DPR, Dewan Perwakilan Daerah, Presiden, dan Mahkamah Agung."

Lebih lanjut dalam Pasal 59 ayat (2) UU 8/ 2011 disebutkan bahwa:

"Jika diperlukan perubahan terhadap undangundang yang telah diuji, DPR atau Presiden segera menin- daklanjuti putusan Mahkamah Konstitusi sebagaimana dimaksud pada ayat (1) sesuai dengan peraturan perundang-undangan."

Diabaikannya atau tidak digunakannya komponen hukum yang berkaitan dengan materi muatan yang akan diatur menyebabkan tertib hukum tidak akan terjadi. Apalagi apabila pembentuk peraturan perundang-undangan menghidupkan kembali norma yang dinilai oleh MK bertentangan dengan UUD NRI 1945. Untuk menghindadari pertentangan antar peraturan perundang-undangan, UU 12/2011 telah menentukan proses pembentukannya. Dalam Pasal 1 angka 1 UU 12/2011 disebutkan bahwa pembentukan peraturan perundangundangan salah satu tahapnya adalah pembahasan. Selengkapnya Pasal 1 angka 1 UU 12/2011 berbunyi sebagai berikut:

"Pembentukan Peraturan Perundang-undangan adalah pembuatan Peraturan Perundang-undangan yang mencakup tahapan perencanaan, penyusunan, pembahasan, pengesahan atau penetapan, dan pengundangan."

Proses pembentukan peraturan perundangundangan berdasar Pasal 1 angka 1 UU 12/2011 tersebut ada 5 (lima) tahap yaitu tahap perencanaan, tahap penyusunan, tahap pembahasan, tahap pengesahan atau penetapan, dan tahap pengundangan. Tahapan penting dalam pembentukan peraturan perundang-undangan terkait dengan materi muatan adalah dalam tahap penyusunan dan tahap pembahasan. Tahap penyusunan, tim perumus pasti melakukan proses penormaan.

Proses penormaan tersebut, tim idealnya memperhatikan peraturan perundang-undangan yang lebih tinggi. Khusus untuk peraturan menteri, karena peraturan menteri merupakan pengaturan lebih lanjut dari peraturan yang lebih tinggi. Tahap penting yang kedua adalah tahapan pembahasan. Tahap pembahasan tersebut, dilakukan proses pencermatan terhadap rancangan materi muatan 
yang telah disusun oleh tim. Dalam proses tersebut dilakukan harmonisasi materi muatan rancangan peraturan perundang-undangan. Proses harmonisasi tersebut dikaji peraturan yang akan dibentuk apakah tumpang tindih dengan peraturan lainnya, peraturan yang akan dibentuk tidak memadai, atau malah peraturan yang akan dibentuk tidak menyelesaikan permasalahan yang akan diatur. Sehubungan dengan putusan MK, sesungguhnya putusan MK adalah acuan pasti mengenai suatu hal apakah bertentangan dengan peraturan yang lebih tinggi atau tidak.

MK sebagai penafsir Undang-Undang dalam beberapa putusannya memberikan acuan dalam pembentukan peraturan perundang-undangan. Acuan tersebut apabila digunakan oleh pembentuk peraturan, dapat dipastikan pengaturannya harmonis. Sebagai contoh adalah putusan MK dalam putusan nomor 2-3/PUU-V/2007 yang merekomendasikan perumusan, penerapan, termasuk pelaksanaan pidana mati harus memperhatikan sungguh-sungguh beberapa hal yang ditentukan oleh hakim MK yaitu kesatu pidana mati bersifat khusus, kedua pidana mati dijatuhkan dengan masa percobaan 10 (sepuluh) tahun, ketiga pidana mati tidak dapat dijatuhkan terhadap anak-anak yang belum dewasa, dan keempat eksekusi terhadap perempuan hamil atau orang yang mengalami gangguan jiiwa eksekusi ditangguhkan. Pembentuk peraturan perundang-undangan tentu saja harus mengacu pada rekomendasi MK tersebut. Pengabaian terhadap putusan MK dapat berakibat norma yang dibuat berpotensi dinilai bertentangan dengan peraturan yang lebih tinggi.

\section{Simpulan}

Berdasarkan pemaparan dalam pembahasan, maka dapat disimpulkan: Pembentukan peraturan perundang-undangan harus memperhatikan seluruh komponen hukum termasuk putusan MK untuk menghindari pertentangan antar peraturan perundang-undangan atau komponen hukum lainnya untuk mewujudkan tertib hukum.

Terdapat peraturan perundang-undangan yang tidak sesuai atau bertentangan dengan putusan MK sehingga menyebabkan ketidakpastian hukum, dalam hal ini adalah pengaturan jenis koperasi dalam Permenkumham 14/2019. Mewujudkan kepastian hukum dalam peraturan perundang-undangan maka disarankan kepada pembentuk perundang-undangan memperhatikan seluruh komponen hukum termasuk putusan MK dalam proses pembentukan peraturan perundangundangan. Hal tersebut sangat penting apalagi terkait dengan pengaturan norma atau suatu hal yang pernah dilakukan pengujian di MK.

\section{Daftar pustaka}

Ali, Achmad. 2017. Menguak Realitas Hukum. Jakarta. Kencana.

Alexander Ch. Liakdja, Jeffry. 2015. Memaknai "Hukum Negara) Law Through State)" dalam Bingkai "Negara Hukum (Rachstaat)". Makassar. Hasanudian Law Review.

Marzuki, Peter Mahmud. 2011. Penelitian Hukum. Jakarta. Kencana Prenada Media Group.

Safaat, Muchamad Ali, dkk. 2010. Hukum Acara Mahkamah Konstitusi. Jakarta. Sekretariat Jenderal Mahkamah Konstitusi Republik Indonesia.

Syahuri, Taufiqurrahman. 2011. Tafsir Konstitusi Berbagai Aspek Hukum. Jakarta. Kencana.

Undang-Undang Dasar Negara Republik Indonesia Tahun 1945.

Undang-Undang Nomor 24 Tahun 2003 tentang Mahkamah Konstitsi.

Undang-Undang Republik Indonesia Nomor 8 Tahun 2011 tentang Perubahan Atas Undang-Undang Nomor 24 Tahun 2003 tentang Mahkamah Konstitusi.

Undang-Undang Republik Indonesia Nomor 12 Tahun 2011 tentang Pembentukan Peraturan Perundangundangan. 
Jurnal Cakrawala Hukum, Volume 11 No. 1 April 2020

ISSN PRINT 2356-4962 ISSN ONLINE 2598-6538

Peraturan Menteri Hukum dan Hak Asasi Manusia Republik Indonesia Nomor 14 Tahun 2019 tentang Pengesahan Koperasi.

Pramasantya, O. (2017). Perjanjian perkawinan pasca putusan Mahkamah Konstitusi nomor 69/PUU-
XIII/2015. Jurnal Cakrawala Hukum, 8(2), 191-200. doi:10.26905/idjch.v8i2.1671.

Putusan Mahkamah Konstitusi Republik Indonesia Nomor 28/PUU-XI/2013. 